\title{
The Impact of the Sports Spirituality on Moral and Ethical Actions of Athletes
}

\author{
Marijan Spehnjak \\ The Roman Catholic Archdiocese of Zagreb, Croatia
}

\begin{abstract}
This paper presents the results obtained by the survey of 207 athlete respondents (handball players) about faith, prayer, the meaning, forgiveness, gratitude, relationship to God and ethical-moral action. All the indicated factors are part of the human aspect of the experience, and in this paper, they have been viewed through a spiritual and religious dimension of a man. Namely, a man is not only a psycho-physical being, he also has a spiritual dimension (Ivančić, 2011; 2016a). The spiritual aspect is connected to virtually every field of the human actions, including the sports one. The sports spirituality and the experience of the spirit are reflected in the decision for the good, true, beautiful, and the one whereas a lack of these realities brings deviations both in life and in sport. The method used was the structured questionnaire (Ćorić, 1997), and for this study 17 questions were selected to test the two dimensions, the inner contents of religiosity and the impact of religiosity on daily life. The survey results showed that to the handball players ethical-moral principles are very important and they make their everyday decisions based on them. For $94 \%$ of Croatian handball player respondents, religion is an important factor when looking for answers to questions about the meaning of life. 98\% of respondents give their best to try to live by their religious belief in both professional and social life regularly or frequently. It is expected that the results of this research will expand the existing knowledge about the impact of transcendental values in making professional sports and everyday decisions, and that it will also contribute to establishing the importance of the moral and ethical education in forming the criteria of value and developing sports spirituality.
\end{abstract}

Keywords: spirituality of sports, religion, the meaning, prayer, religiosity, moral act

\section{Introduction}

In the modern society, sport has become one of the special phenomena, a matrix of mentality and behavior, especially interesting due to the fact that the whole person with his psycho-physical and spiritual aspect is involved in the activity. Sport as one of the segments in human life, raises the man at all his levels. A successful athlete, coach and theorist Antun Šafarić points out that "sport should achieve specific biological, social and educational goals. Sport develops freedom of creation and turns a man into the subject, and not just an object (Šafarić, 2012: 4).

The center of the action in the world of sport, a sense of hard work and sacrifice are looking for their purpose. Based on the value of choice, the modern professional athlete faces many challenges but also contingencies. For Šafarić the goal of sport is not only health, money and fame, but sport also helps fight the alienation of the today's modern man. In sport a man can find the fulfillment and freedom, pleasure of the victory over the opponent, but also over himself (Šafarić, 2012: 10). In today's technologically advanced society that is influenced by a strong utilitarian-materialistic worldview there is a need to determine its influence on the sporting actors, due to the "consumerist behavior applied to sport reduces the social sensitivity by concentrating on the result" (Mieth, 1993: 43).

Questioning of the moral values through sport, the relationship of religion and sport, religious practice and prayer have become the subject of the research that preoccupies the public attention. The man is by nature homo religious or naturaliter religiosus (Jukić, 1997: 21), and this fact translates into all aspects of human labor and creativity, and thus on the sporting action. Sport has nowadays become an important and widely shared area of interest, and the question of the religiosity, the spirituality, the meaning, prayer and the faith within oneself have an exceptional actuality due to the increasing alienation of the modern man.

The research topic is the communicative aspect of faith and prayer, the relationship with God and the ethical-moral action of handball players. The aim was to explore how the indicated factors (prayer and faith, ethical-moral action) influence the commitment, decisions and activities of athletes in their everyday life.

This paper aims to answer the following research questions:

1. To what extend are the transcendental values, such as prayer, faith, meaning, forgiveness, thanksgiving and kindness important for the tested handball players?

2. What visible phenomena manifest the sports spirituality?

3. Are there any differences with regard to socio-demographic characteristics of the respondents? 


\section{The theoretical propositions and the definition of the terms}

Although the modern man has for several decades systematically been directed exclusively towards materialistic values, the questions of meaning, religiosity, spirituality, prayer, faith, ethics and moral behavior seem to remain eternal. The research conducted by Brkljačić et al. on the attitudes of athletes about ethics in today's sports have shown that athletes recognize ethical moments in sport, in terms of what is and what is not moral, but also point to the inability to define and recognize ethical dilemmas in sport. The authors note the importance of systematic education (Brkljačić-Žagrović; Brkljačić-Beg; Mavrinac; Sorta-Bilajac Turina; Bunjevac and Čengić, 2011: 93). Šafarić emphasizes that the importance of ethics in sports must never be forgotten. Morality is considered here to be a human practical and everyday positive attitude towards the athletes themselves, the opponent as well as the environment (Šafarić, 2012: 14). According to Poupard for several decades, radical laicization of the society has systematically been carried out so "the individual and subjective conscience" have been developed (Poupard, 1985, according to Tomasević, 2015: 161) thus producing a crisis of the system that gave meaning. One of the most prominent founders of the sociology of religion Esad Ćimić warns that the "moral crisis the most serious one in terms of its consequences" (Ćimić, 1986: 253). Although the secularization has increased the laicization and has led to a decline in devotional practices, it has not decreased religiosity of man. An influential religiosity scientist Berger points out that today's world is with some exceptions deeply religious (Berger, 2008). According to Perak, the testimony of world religious traditions emphasizes the experience of the holy as a starting sacred dimension of the universal human activity, be it the awakening of Buddha in meditation, Moses' vision of the burning bush, Paul's glare on the road to Damascus, or Mohammed publication of the Koran (Perak, 2010: 237). James W. Fowler (1981) considers religiosity universal and regulated, interactive and social, but also that it depends on education and the environment. Tomislav Ivančić says that religiosity is in every human being as an innate ability to search for meaning, and on its basis religions arise (Ivančić, 2016a: 123). The European Values Study conducted on the general population in Croatia in 2008 showed that $79 \%$ of people consider themselves religious, $10 \%$ unreligious, $4 \%$ consider themselves to be atheists and $6 \%$ of respondents did not know (Črpić and Zrinščak, 2010: 10). However, in some countries, studies have shown different results. For example, research on the religiosity of young people in Germany has shown that $42 \%$ of young people suspected the existence of God (Brant, 2006 as quoted by Leutar and Josipović, 2008: 405). An international survey conducted in the late nineties in Austria, Croatia and Poland gave similar results. The more economically developed country and the greater degree of modernization of society, the lower the proportion of young people who are religious (Leutar, 2000 as quoted by Leutar and Josipović, 2008: 405). Comparing the terms of religiosity and spirituality, Fukuyama and Sevig (1999) point out that there is no single definition of religion and spirituality. For Dučkić and Kokoric these terms "often terminological overlap but there are some visible distinctions between them" (Dučkić and Kokorić, 2014: 426). Hassed describes spirituality as a universal, broader construct that refers to the subjective experience of transcendence that exists outside the religious framework, while religiosity is often characterized by the typical certain rituals within the religious institutions (Hassed as quoted by Dučkić and Kokorić, 2014: 243). Leutar points out that spirituality today has become a modern word and often brings to mind the esoteric, Eastern religions and new movements (Leutar and Leutar, 2010: 82). Today the understanding of the religious and spiritual aspects of man is crucial. The inner aspect of man, his spiritual dimension, goes beyond the psychological and somatic area. One of the most prominent Croatian Catholic theologian, doctor emeritus Tomislav Ivančić explores the functions of the spiritual laws of a man. The research topic of his scientific and therapeutic work is a spiritual soul in man. Through research discipline hagiotherapy he has come up with new cutting-edge knowledge of the man and the laws of the spirit and its functioning. The author points out that this is not yet another psychotherapeutic method that would want to help the man, but an anthropological study of man as a whole (Ivančić, 2011: 109-184). Ivančić reveals that the spirit tends to his development, but a man experiences the greatest frustration if he does not develop in all its aspects.

Sports spirituality

The man as the main protagonist and actor of sporting activities inevitably spiritualizes sport through his symbolic-communicative dimension. Parry et al. in their book Sport and Spirituality and introduction say that sport can be presented through the many aspects of human work, but also say that the spiritual dimension is the base for participation and success in the sport. As scientists and experts, the authors observe sports spirituality through the lens of psychology, ethics, theology and contemporary spirituality (Parry; Nesti, Robinson and Watson, 2007). Many sports sociologists in their studies recognize the interaction between sport and religion and the importance of religion and spirituality in the life of an athlete (Coakley, 2003; Hoffman, 1992; Stevenson, 1991, according to Watson, and Czech, 2005: 26). Watson and Nesti (2005) discuss spirituality in sports psychology, describing that spirituality can be understood in the context of sport, and that it may be included in relationship of counseling and mental preparation. For Kučiš and Spehnjak it is important that a person develops the physical, intellectual and spiritual aspect, as it builds and develops as the complete personality (Kučiš and Spehnjak, 2015). It is not enough to accept sports activity only as a physical category to 
achieve sports results, but also to accept it as a spiritual-moral category as it then becomes a source of joy, satisfaction, fulfillment and purpose. Brkljačić warns of various temptations of the utilitarian approach which in sport present various risks, such as political or economic interference and winning at any cost (Brkljačić, 2007: 232). Such an approach can lead to the development of double standards thus stopping the development of value spheres in a man; a young man is left to the moral disorientation. Today, the young athlete is exposed to distinct physical and psychological stress, demanding training and high expectations. A pragmatic approach to the sport, which is particularly visible in the media public sphere, demands of a young sportsman strength, stability, discipline, order, perseverance and consistency in personal engagement. The demanding sports engagement is for many athletes easier accomplished with faith and prayer as extra power to restore the power. Today scientists conduct numerous research on the effect of prayer as spiritual help to overcome stressful situations, trainings and competition, fears and their own borders (Czech; Wrisberg; Fisher; Thompson and Hayes, 2004; Kučiš and Spehnjak, 2015). The results of research on the religiosity of athletes according to Kučiš and Spehnjak have showed that $86 \%$ of respondents pray always or sometimes before their performance (2015: 43). Faith, prayer and relationship to the transcendent fall into the category of basic human activities and spiritual reality that is revealed through various observable phenomena. Namely, "the phenomenon is a manifest sign, something that can be recognized and through that sign get closer to the knowledge of the hidden source of the sign" (Ivančić, 2013: 118). Based on observable phenomena a strong and positive spirituality can clearly be identified in athletes as it stands out through the decision for the moral good, tolerance, self-giving, self-control, perseverance, initiative, sense of duty and responsibility, positive speech, sacrifice, fair play, trust, faith, love, solidarity, overcoming egoistic aspirations. In his studies of the human spirit, Ivančić says that the experience of the spirit manifested through the so-called transcendental, i.e. its characteristics, and those are "unum, bonum, verum and pulchrum - one, good, true and beautiful" (Ivančić, 2013: 76). Applying the Ivančić theory of spirit to the sports area, the lack of transcendental is clearly recognized through the visible phenomena. For example, the lack of truth in cases when the lies and fraud are means in trying to achieve success, when they ignore the rules, take stimulants and drugs, actively or passively rig the results. The lack of goodness is manifested through arrogance, orientation solely towards self-realization and their own interests or turning a blind eye to the needy, negative speech, emphasis on the importance of points and wins. The lack of beauty in the absence of creativity and life optimism. The lack of unity through lack of vision of one's own development, not recognizing their integrity, gifts and talents to be developed, exaggerated individualism, an exclusive focus on their own success without worrying for the success of your team, etc. The causes of many conflict communication situations are in the intrapersonal area. The center of the intrapersonal aspect is the area of the spiritual dimension of man. This center may be underdeveloped, then we can talk about the lack of integrity that can be recognized through the lack of the transcendental. The essence of the spiritual dimension are the steady growth and development. One of the powerful tools for this growth is building positive habits. It is impossible to fight against the negative habits, but by perseverance on an everyday basis and step-by-step building of the positive habits, the negative ones will be eliminated. This persistent effort and goal-oriented behavior leads to victory. Doctor Bruce $\mathrm{H}$. Lipton claims that the habits play a decisive role in human life, since they are stronget than the genetic code. The man himself decides what he will write in his genome (Lipton, 2007). In sports, a man not only wins the competition, but he must also first conquer himself and his shortcomings to reach the unprecedented possibilities, and his spiritual aspect enables him to do so. According to Ivančić health spirit is expressed through a decision for good. Goodness is itself a fundamental reality, not just a moral-ethical value. It is a condition for existence, it is absolute and indestructible. The author warns that a man may be a passionate athlete, but "he can also be passionately irritable, passionately devoted to drinking, drugs, gambling, have furious outbursts towards some people; he may be hasty, nervous, restless, resentful, and out of the control and with no limits" (Ivančić, 2013: 103). By the means of the internal intrapersonal aspect a man establishes a connection to the deep center in himself. Any inability to establish connections to the deep center in oneself has its causes in internal disorder that the Christians call an evil or a sin. The modern man rejected the notion of sin as something backward and restrictive. But Jesus says, "Whoever commits sin is a slave of sin" (John 8:34). Since the slave is not free, he cannot break free on his own, but he needs deliverance: "What is impossible with man is possible with God" (Mt 19, 26). The facts that the Christians keep losing the sense of sin and evil, but also have the spiritual category not only the materialist has been proven by the survey conducted in Croatia as part of the international project of The European Values Study in 2008. It showed that only $60 \%$ of Catholics believe in sin (Blažević, 2014: 23). Migles points out that "the greatest danger of our time is relativisation of everything. Good and evil have become the matter of the personal choice" (Migles, 2016: 16). Man's conflict is in the choice of values, adopting a materialistic and hedonistic worldview and it may drop to a level of just physical or psychological life, but in doing so he "has disabled himself with evil that cannot hear and act as dictated by the spiritual soul." (Ivančić, 2013: 88). Apart from sin, various insults, rejection, failure, lack of affection, negative relationships can deeply hurt and crush the inner spiritual strength. Such a person feels extremely hurt and powerless. Pope John Paul II in the encyclical Salvifici Doloris emphasizes that spiritual 
suffering is far more difficult than mental or physical suffering, but that it is also the least recognizable (SD 5). The health of spirit is expressed through a decision for good. Focusing on the construction of virtue and virtue leads to a strengthening of the spiritual structure of man. The important positive thoughts, positive speech and orientation to transcendentalism is of crucial importance here. Doctor Lipton, points out that "the positive thoughts have a huge effect on the genes, but only when they are in accordance with the subconscious programming. The negative thoughts have an equally powerful effect" (Lipton, 2007: 31). The task of every person is to recognize their value, discover their originality and meaning of existence. Only by doing so his development will be immense as well as the fruits of his work, creativity and creation. Such a man will enrich the sports by being himself and with his gifts and the sport will become an art. Since man is the highest value, regardless of race, gender, religion, culture to which it belongs, the job he is in, no matter how successful or less successful he is, recognizing the man as the greatest achievement of the ability is the highest level of the capability of the human spirit.

\section{Hypotheses}

The paper starts with a man as complex and ontological whole being. Based on the set objectives through theoretical and empirical part of the work the following hypotheses are defined:

H/1 The complexity of man consists in the psycho-physical and spiritual dimension. In order to accomplish himself meaningfully, he must grow, thrive and prosper through every of his aspects.

H/2 Faith, prayer, searching for meaning, thanksgiving, forgiveness, relationship with God and his commandments affect the intrapersonal aspect of man, shape his attitudes and influence the moral-ethical action. H/3 There was no statistically significant difference in the average scores given to gender.

\section{Research methods}

To determine the intensity of faith, prayer, thanksgiving, forgiveness, relationship to the transcendent, it is necessary to access the empirical research. The basic research method is the method of the survey. As a basic research tool, the questionnaire on dimensions of religiosity and its impact on daily life was selected. The above mention questionnaire was compiled by Šimun Šito Ćorić based on many years of experience, taking into account the underlying psychological and theological knowledge, and it appears in its present form after additional expert advice and training. The questionnaire was based on studies that are relevant to this case measurements (C.Y. Glock and R. Stark, 1965, 1966 and M. King and R. Hunt, 1967, 1969). Although it was intended for the population of Catholic tradition, with a few adaptations it can easily be applicable to other Christian communities and other religions (Ćorić, 1997: 274-275). The respondents will use the method of selfperception to assess their attitudes toward faith, prayer, the sense of God, the influence of moral values on everyday decision-making process. For the purposes of this study the selected variables were used and they referred to two thematic areas: A) indoor facilities religiosity and B) the impact of religiosity on daily life. 13 questions were selected for the questionnaire, and the results were presented in the form of scales of one to four, and mostly were read as follows: $(1=$ never, 2 = sometimes, $3=$ often, 4 = regularly $)$.

Sample

The study was conducted in collaboration with the Zagreb Handball Association in the period from May to October 2016. Upon the arrival to the club the surveys were handed to the athletes. The right to obtain information of respondents was respected. Furthermore, they gave the consent to participate in the survey and the anonymity of respondents had been guaranteed. The emphasis was put on the fact that the survey is a contribution exclusively to the scientific discourse. The study included all clubs within the jurisdiction of the Zagreb Handball Federation, and included 19 male handball clubs (RK $=$ HC handball club, ŽRK $=$ FHC female handball club - RK PPD Zagreb, RK Dubrava, RK Medveščak, RK Maksimir Pastela, MRK Metalac, MRK Sesvete, RK Zg-Dubrava, RK Zagorica, RK Odema, RK Rekreativac, RK Trnje, RK Pavleki, RK Libra Tehničar, RK Silent, RK Bundek Novi Zagreb, RK Rudeš, RK Sesvete-Zagreb, RK Jelenovac, RK Agram), 7 female handball clubs (RK Lokomotiva, RK Sesvete Agroproteinka, RK Trešnjevka, ŽRK Dubrava, RK Libra Tehničar, RK Rekreativac, RK Breza) as well as 4 handball clubs located outside the city of Zagreb but still are the members of the Zagreb Handball Federation (RK Zlatar Bistrica, ŽRK Zagorec, RK Bedekovčina, RK Zabok).

The survey was conducted on a sample of $\mathrm{N}=208$ respondents. With regard to the gender $53 \%$ were male and $46 \%$ female respondents. In this sample, it is mainly younger respondents aged between 18 and 25 years $(92 \%)$, mostly with secondary education (86\%), with the residance in a town (92\%) and unmarried (94\%) and middle class $(84 \%)$.

The research results are limited to the Zagreb County and are indicative but given the specific population and complex research they can be integrated in the whole Croatian area and the wider European area. 


\section{Faith and meaning}

\section{Research Results}

Faith is a spiritual commitment, the inner and individual reality which directs and determines the external action. Religion monitors a person's entire life, affects the perception of the world, life, worldview and the meaning of life. Fowler (1981) understands religion as a universal human phenomenon whose content is not necessarily associated with religiosity. His theory of human development and degrees of faith or religiosity is quite significant. Shiah et al. (2015) point out that the search for the meaning of life, especially in difficult life situations, is one of the greatest human motivation driven by a man. The respondents were asked to estimate how often they turn to religion as a particularly important factor when looking for answers to questions about the meaning of life.

1. (A) How often is the faith important in responding to questions about the meaning of life?

\begin{tabular}{|l|r|r|}
\hline $\begin{array}{l}\text { Table 1. The faith is very important in responding to } \\
\text { questions about the meaning of life }\end{array}$ & Total & Portion \\
\hline never & 2 & $1 \%$ \\
\hline sometimes & 10 & $5 \%$ \\
\hline often & 87 & $42 \%$ \\
\hline regularly & 109 & $52 \%$ \\
\hline Total & 208 & $100 \%$ \\
\hline
\end{tabular}

The analysis of the results (Table 1) shows that the faith is regularly or often important for $94 \%$ of respondents as a source of answers to questions about the meaning of life. Religion has no effect on the $1 \%$ of the surveyed athletes and sometimes has an impact on $5 \%$ of the respondents. The total average rating of all respondents is $\mathrm{M}=3.46$. According to the differences in gender there is no significant difference in the responses to this question.

\section{Prayer in the case of need}

Prayer is the most widespread religiously motivated activity (Ćorić, 1997: 52). Every athlete sometimes faces crises, fears, stress conditions and their own limits. Respondents were asked to estimate how often in need or distress pray to God.

2. (A) How often do you in the case of need or distress pray to God?

\begin{tabular}{|l|r|r|}
\hline Table 2. In the case of need or distress pray to God & Total & \multicolumn{2}{|c|}{ Portion } \\
\hline never & 0 & $0 \%$ \\
\hline sometimes & 3 & $1 \%$ \\
\hline often & 57 & $28 \%$ \\
\hline regularly & 147 & $71 \%$ \\
\hline Total & 207 & $100 \%$ \\
\hline
\end{tabular}

The results show that $99 \%$ of respondents frequently or regularly pray in the case of need or distress. Only $1 \%$ of respondents prays sometimes, none of the respondents answered negatively to this question. The total average rating of all respondents was $\mathrm{M}=3.7$ and the differences in the average scores (t-test for independent samples - Figure 2. 1.) are significant according to gender and it shows that women $(\mathrm{m}=3.82)$, on average, are more likely than men $(\mathrm{m}=3,59)$ to pray in case of need and distress $(\mathrm{t}=-3,522 ; \mathrm{p}<0.001)$.

Picture 2. 1. In the case of need or distress pray to God (comparison women vs. men at average estimates)

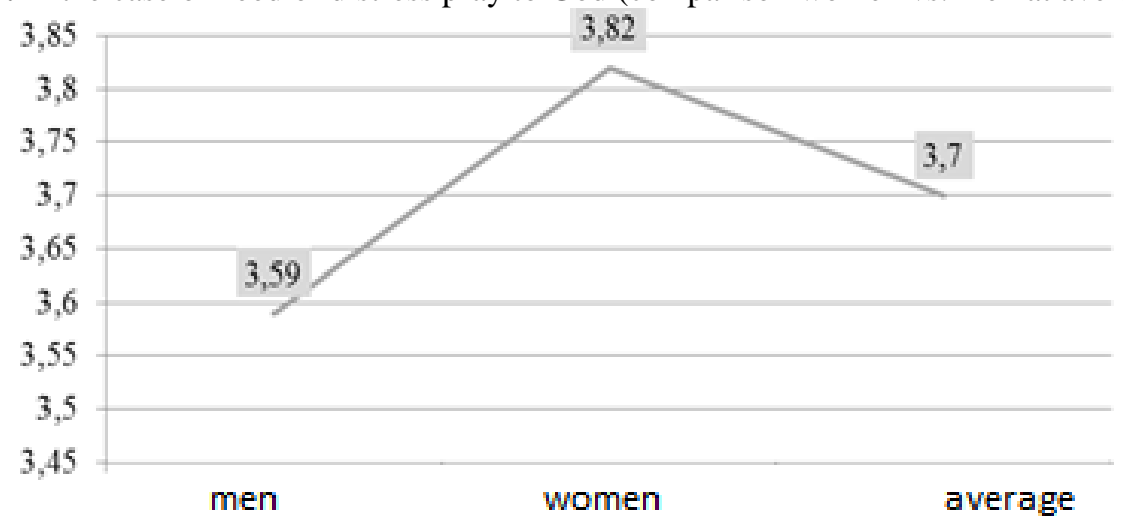


God's will

The intimate companionship with God, the trust in his providence brings inner freedom and peace in everyday decision making. The respondents were asked to estimate how often during everyday decision making they wonder what God wants.

3. (B) How often when making everyday decisions, do you wonder what God wants?

\begin{tabular}{|l|r|r|}
\hline $\begin{array}{l}\text { Table 3. How often when making everyday decisions, do you wonder } \\
\text { what God wants? }\end{array}$ & Total & Portion \\
\hline never & 1 & $0 \%$ \\
\hline sometimes & 25 & $12 \%$ \\
\hline often & 44 & $21 \%$ \\
\hline regularly & 136 & $66 \%$ \\
\hline Total & 206 & $100 \%$ \\
\hline
\end{tabular}

The analysis of the results (Table 3 ) shows that $66 \%$ of respondents regularly when making everyday decisions ask themselves what God wants, and yet $21 \%$ do that often, so for the vast majority of respondents (87\%) considering the God's will is a very common practice when making everyday decision. $12 \%$ of respondents it does so sometimes, and only one respondent claimed never to do so. The total average rating of all respondents is $\mathrm{M}=3.53$ with no difference in regard to gender.

Do good

There us is a natural mechanism of satisfaction to do someone good inside every man. Therefore, we asked the respondents to estimate how often they try to do good even to those they know will not do well in return.

4. (B) I try to do well even to those I know will not do well in return.

\begin{tabular}{|l|r|r|}
\hline Table 4. Try to do well even to those they know will not do well in return & \multicolumn{1}{|c|}{ Total } & 0 \\
\hline never & $0 \%$ & $0 \%$ \\
\hline sometimes & 5 & $2 \%$ \\
\hline often & 103 & $50 \%$ \\
\hline regularly & 207 & $48 \%$ \\
\hline Total & $100 \%$ \\
\hline
\end{tabular}

The results show (Table 4) that $48 \%$ of respondents regularly seek to help without the expectation of the people returning the favour, and 50\% do it often, so for the vast majority of respondents (98\%) this is a very common practice. $2 \%$ of respondents do this sometimes. None of the respondents commented that they would not do good even to those they knew would not do well in return. The total average rating of all respondents is $\mathrm{M}=3.45$ and differences in average scores ( $\mathrm{t}$-test for independent samples - Figure 4. 1.) is significant in terms of gender and reveals that women $(\mathrm{m}=3.64)$ on average are more often prone to do good even to those they know will not do well in return when compared to men $(\mathrm{m}=3,3)(\mathrm{t}=-4.695, \mathrm{p}<0.001)$.

Picture 4. 1. Try to do well even to those they know will not do well in return (comparison women vs. men at average estimates).

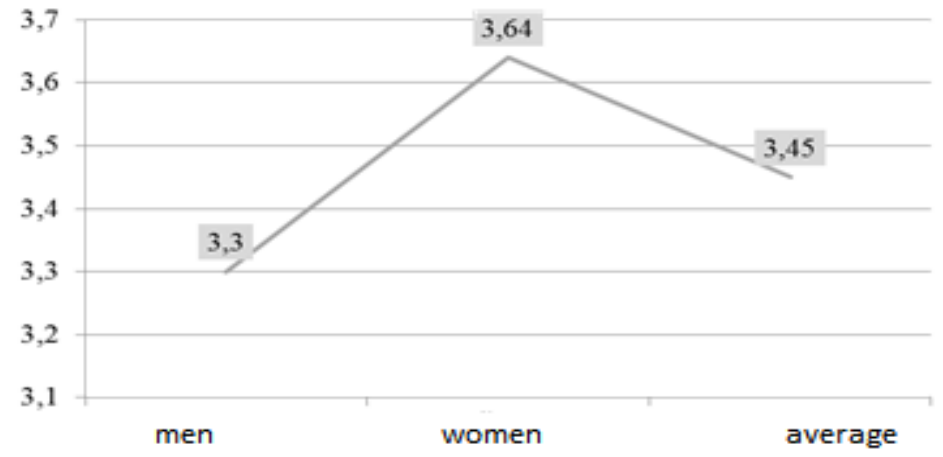

Religious belief

In this modern society marked by utilitarian materialist mentality it is not easy to truly carry out their own religious views and beliefs in daily and professional life. Respondents were asked to estimate how often they live by their religious beliefs and in their professional and social life. 
5. (B) Life in accordance with my religious beliefs and in my professional and social life.

\begin{tabular}{|l|r|r|}
\hline $\begin{array}{l}\text { Table 5. Life in accordance with my religious beliefs and in my professional } \\
\text { and social life }\end{array}$ & Total & Portion \\
\hline never & 0 & $0 \%$ \\
\hline sometimes & 5 & $2 \%$ \\
\hline often & 84 & $42 \%$ \\
\hline regularly & 113 & $56 \%$ \\
\hline Total & 202 & $100 \%$ \\
\hline
\end{tabular}

The results show (Table 5) that $56 \%$ of respondents regularly tries to live according to religious beliefs in both their professional and social life, $42 \%$ do so often, so for the vast majority of respondents (98\%) this is a very common practice. $2 \%$ of respondents do so sometimes. The total average rating of all respondents is $\mathrm{M}=$ 3.53 and differences in average scores ( $\mathrm{t}$-test for independent samples - photo 5. 1) are significant in terms of gender and reveals that women $(\mathrm{m}=3.64)$ on average are more often prone to live by their religious belief professional and social life when compared to men $(\mathrm{m}=3.44)(\mathrm{t}=-2.567, \mathrm{p}<0.001)$.

Picture 5. 1. Life in accordance with my religious beliefs and in my professional and social life (comparison women vs. men at average estimates).

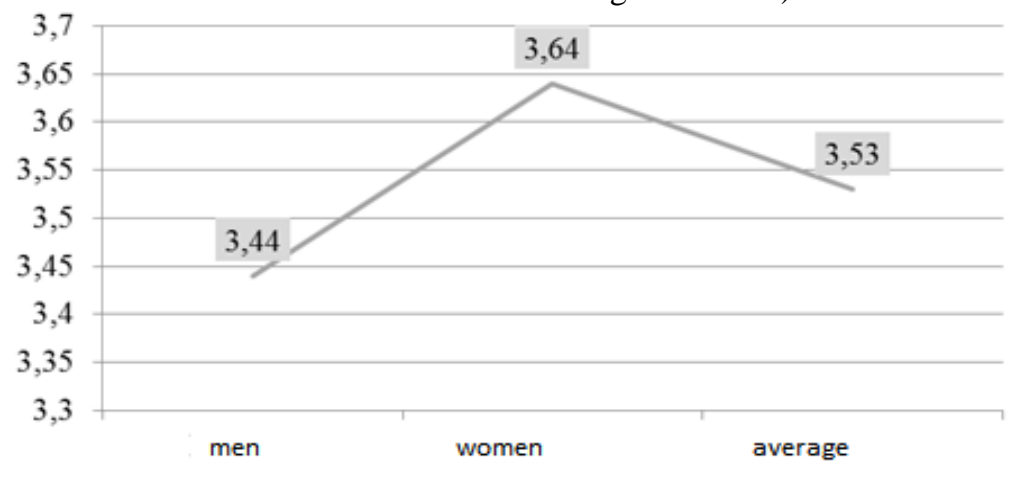

\section{Decalogue}

6. (A) Do they consider the life in accordance to the 10 Commandments obsolete?

Every religion requires its followers to adhere to certain ethical principles. Decalogue or 10 Commandments is a basic code of morality recognized as a moral foundation in Judaism, Christianity and Islam (Brnčić, 2006). Respondents were asked to assess whether the behavior in accordance with the 10 Commandments is obsolete.

\begin{tabular}{|c|c|c|}
\hline Table 6. Consider the life in accordance to the 10 Commandments obsolete & Total & Portion \\
\hline totally agree & 0 & $0 \%$ \\
\hline partially agree & 3 & $1 \%$ \\
\hline mostly agree & 45 & $22 \%$ \\
\hline disagree & 159 & $77 \%$ \\
\hline Total & 207 & $100 \%$ \\
\hline
\end{tabular}

In Table 6 the results show that $77 \%$ of respondents express complete disagreement with the statement that the 10 Commandments is obsolete, and another $22 \%$ partially disagree. Therefore, for the vast majority of respondents $(99 \%)$ the life in accordance with the God's Commandments is not obsolete. The total average rating of all respondents is $\mathrm{M}=3.75$ with no difference in terms of gender.

Moral Action

7. (B) When you are absolutely sure that no one will discover it, will you take something not yours or will you commit a fraud?

Fraud and falsehood are against the common good and the moral code. Respondents were asked to estimate how often they tend to take something not theirs or commit a fraud when sure no one will discover that.

\begin{tabular}{|l|r|r|}
\hline $\begin{array}{l}\text { Table 7. Take something not yours or will you commit a fraud } \\
\text { when sure no one will discover that. }\end{array}$ & Total & Portion \\
\hline never & 0 & $0 \%$ \\
\hline sometimes & 6 & $3 \%$ \\
\hline often & 74 & $36 \%$ \\
\hline regularly & 128 & $62 \%$ \\
\hline Total & 208 & $100 \%$ \\
\hline
\end{tabular}


The results show (Table 7) that $62 \%$ of respondents would never take something not theirs or commit a fraud when sure no one will discover that. However, $36 \%$ of respondents will take or cheat sometimes and $3 \%$ of respondents often do so. The total average rating of all respondents is $\mathbf{M}=3.59$ with no difference in terms of gender.

\section{Gratitude}

8. (A) Do you give thanks to God when you experience something exceptionally good or nice?

Thanking is a virtue of a conscious person who knows that everything they have is a gift. Respondents were asked to estimate how often thank God when they give thanks to God when you experience something exceptionally good or nice.

\begin{tabular}{|l|r|r|}
\hline $\begin{array}{l}\text { Table 8. Do you give thanks to God when you experience something } \\
\text { exceptionally good or nice? }\end{array}$ & Total & Portion \\
\hline never & 0 & $0 \%$ \\
\hline sometimes & 4 & $2 \%$ \\
\hline often & 91 & 111 \\
\hline regularly & 206 & $54 \%$ \\
\hline Total & & $54 \%$ \\
\hline
\end{tabular}

The results show (Table 8) that 54\% of respondents regularly thanked God when they experience something exceptionally good or nice, and $44 \%$ do it often, so for the vast majority of respondents ( $98 \%)$ this is a very common practice. $2 \%$ of respondents are grateful sometimes. The total average rating of all respondents is $\mathrm{M}=3.52$, and the differences in the average scores ( $\mathrm{t}$-test for independent samples - Figure 8. 1.) are significant in terms of gender and reveals that women $(\mathrm{m}=3.45)$ on average are less prone to give thanks to God during very nice event when compared to men $(\mathrm{m}=3.58)(\mathrm{t}=1.664, \mathrm{p}<0.05)$.

Picture 8. 1. Give thanks to God when experiencing something exceptionally good or nice (comparison women vs. men at average estimates).

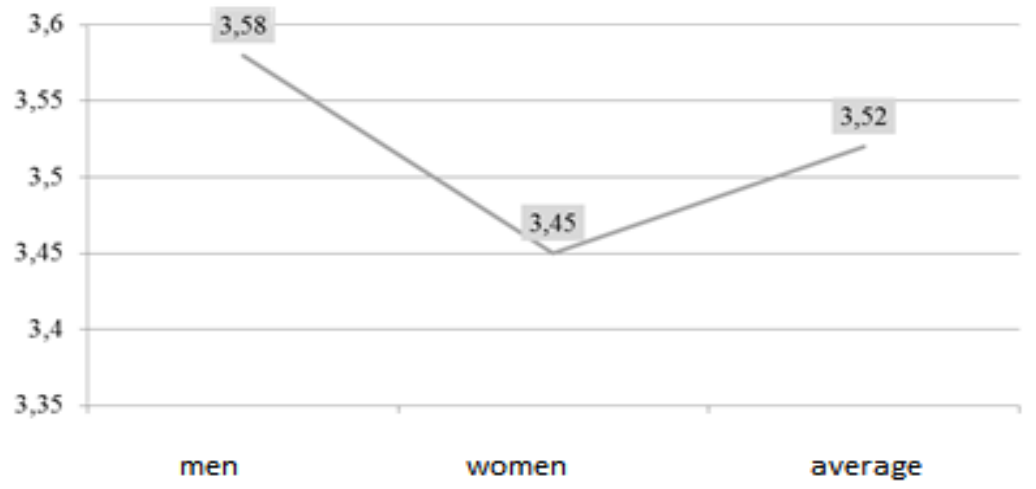

\section{Forgiveness}

9. (A) Do they pray God for forgiveness if they make mistakes?

Proverb says that to err is human and to forgive is divine - and to ask for forgiveness. According to Ivančić it is simply impossible not to make a mistake. By justifying oneself and defending from criticism and the warnings, evil remains in the man. Admitting an error is a ticket to the truth and thus in freedom (Ivančić, 2016a: 93). Respondents were asked to estimate how often they pray to God for forgiveness if they make mistakes.

\begin{tabular}{|l|r|r|}
\hline Table 9. Praying for forgiveness if making a mistake & Total & \multicolumn{1}{|c|}{ Portion } \\
\hline never & 0 & $0 \%$ \\
\hline sometimes & 10 & $5 \%$ \\
\hline often & 86 & $44 \%$ \\
\hline regularly & 101 & $51 \%$ \\
\hline Total & 197 & $100 \%$ \\
\hline
\end{tabular}

Table 9 shows the results that $51 \%$ of respondents regularly asks God for forgiveness if they make a mistake, and $44 \%$ do it often, so for the vast majority of respondents $(95 \%)$ this is a very common practice. $5 \%$ of respondents sometimes pray for forgiveness. The total average rating of all respondents is $\mathrm{M}=3.46$ with no difference in terms of gender. 
Denying your religious belief

10. (B) Willingness to publicly deny their religious belief

Freedom of religion is one of the fundamental human rights including freedom of expression of their faith. Respondents were asked to assess in what situations they might deny their religious beliefs publicly.

\begin{tabular}{|l|r|r|}
\hline Table 10. Willingness to publicly deny their religious belief & Total & Portion \\
\hline any time & 0 & $0 \%$ \\
\hline in greter need & 22 & $11 \%$ \\
\hline in case the existance was in danger & 32 & $15 \%$ \\
\hline in case the life itself was in danger & 154 & $74 \%$ \\
\hline Total & 208 & $100 \%$ \\
\hline
\end{tabular}

As it can be seen in Table 10, the results show that $74 \%$ of respondents would publicly deny their religious beliefs only when it comes to protecting their life or their loved ones, and $15 \%$ in the case of their endangered existence or their loved ones, so the vast majority of respondents (89\%) is ready to deny their religious beliefs only in extreme situations. $11 \%$ of respondents would do so in case of the greater need. The total average rating of all respondents is $\mathrm{M}=3.63$ with no difference in terms of gender.

Satisfaction with oneself

11. (B) The level of satisfaction with oneself

Overcoming the challenges and achieving their goals, help build self-confidence and satisfaction with oneself. Respondents were asked to assess whether they are satisfied with themselves when thinking about themselves (who they are, what they are and what are).

\begin{tabular}{|l|r|r|}
\hline $\begin{array}{l}\text { Table 11. When thinking about myself (who I am, what I am and } \\
\text { what I am like) }\end{array}$ & Total & Portion \\
\hline not satisfied at all & 0 & $0 \%$ \\
\hline mostly satisfied & 3 & $1 \%$ \\
\hline more satisfied than not & 126 & $38 \%$ \\
\hline very satisfied & 208 & $61 \%$ \\
\hline Total & & $100 \%$ \\
\hline
\end{tabular}

In Table 11 the results show that $61 \%$ of respondents are very satisfied with themselves, and $38 \%$ are more satisfied than dissatisfied, so the vast majority of respondents (99\%) expressed a high degree of satisfaction with themselves. None of the respondents expressed they were not satisfied at all. $1 \%$ of respondents said they are mostly satisfied. The total average rating of all respondents is $\mathrm{M}=3.59$ with no difference in terms of gender.

\section{Love to God and your neighbour}

12. (B) The effort to maintain order: "Love God with all your heart and your neighbor as yourself."

Love is the foundation of every religion. Love is the fullness of the Decalogue. To strive to love means to strive for perfection. Respondents were asked to estimate how often they try to live by the order "Love God with all your heart and your neighbor as yourself."

\begin{tabular}{|l|r|r|}
\hline $\begin{array}{l}\text { Table 12. The effort to maintain order: "Love God with all your heart } \\
\text { and your neighbor as yourself" }\end{array}$ & Total & Portion \\
\hline never & 0 & $0 \%$ \\
\hline sometimes & 6 & $3 \%$ \\
\hline often & 130 & $35 \%$ \\
\hline regularly & 208 & $63 \%$ \\
\hline Total & $100 \%$ \\
\hline
\end{tabular}

In Table 12 the results show that $63 \%$ of respondents regularly try to keep the commandment of love for God and their neighbor, and $35 \%$ is trying to keep it often, so for the vast majority of respondents (97\%) this is a very common practice. $3 \%$ of respondents do it sometimes. The total average rating of all respondents is $\mathrm{M}=$ 3.60 with no difference in terms of gender.

The sense of God's presence

13. (A) The sense of God's presence

Man is a psycho-physical as well as spiritual being. It is the spirit that enables the man to communicate with God (Ivančić, 2016a). Respondents were asked to assess how often they are found in situations where they feel God's presence and influence. 


\begin{tabular}{|l|r|r|}
\hline Table 13. There are moments when they sense God's presence & Total & \multicolumn{1}{|c|}{ Portion } \\
\hline never & 0 & \\
\hline sometimes & 3 & $0 \%$ \\
\hline often & 87 & $1 \%$ \\
\hline regularly & 117 & $52 \%$ \\
\hline Total & $57 \%$ \\
\hline
\end{tabular}

In Table 13 the results show that $57 \%$ of respondents regularly feel the presence of God, and $42 \%$ felt it often, so for the vast majority of respondents (99\%) the sense of God's presence is a regular or frequent occurrence. The total average rating of all respondents is $\mathrm{M}=3.55$ and the differences in average scores ( $\mathrm{t}$-test for independent samples - Figure 13.1.) are significant in terms of gender and show that women $(\mathrm{m}=3.66)$, on average, are more likely feel that way when compared to men $(\mathrm{m}=3.45)$ to $(\mathrm{t}=-2,875 ; \mathrm{p}<0.01)$.

Picture 13. 1. The level of sensing of God's presence (comparison women vs. men at average estimates).

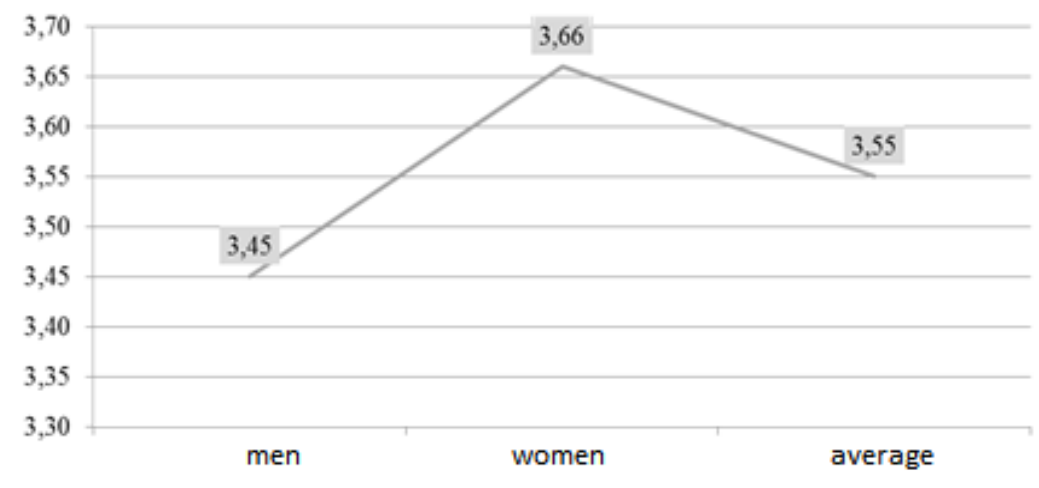

III. Discussion And Interpretation Of The Results

Self-realization, self-confidence, progress and growth in all segments are extremely important for every athlete. The purpose of the first hypothesis was to point out the complexity of the human being which consists of his psycho-physical and spiritual dimension that seeks to grow. In order to grow sensibly, a man must grow, thrive and develop through every aspect. When asked how the respondents are satisfied with themselves, $61 \%$ of respondents are very satisfied, $38 \%$ more satisfied than not, only $1 \%$ of the respondents are mostly satisfied with themselves. The high levels of satisfaction among other things includes the religious and spiritual development of the athletes surveyed as well as the commitment to good.

The obtained data show that faith, prayer, searching for meaning, thanksgiving, forgiveness, an encounter with God, commitment to good are an integral aspect of human experience and activity. All the indicated factors are in direct connection with the religious and spiritual experience inherent to the anthropological dimension of man. As the results show a very high percentage of handball players who consider these factors an important part of their experience, we can confirm the second hypothesis about the importance of the specified factors when making decisions. When asked How often is the faith important in responding to questions about the meaning of life, $94 \%$ of respondents their belief is regularly or often a source of answers to questions about the meaning of life. Comparing these results with the research results from 2014 involving football players, basketball players, volleyball players, water polo players and track and field athletes, when answering the question if the faith helps in the sport, the results showed that the respondents always (55\%) or at least sometimes (38\%) leaned on the power of faith (Kučiš and Spehnjak, 2015: 43).

The European Values Survey (2008) conducted on the general population in Croatia questioning attitude toward religion, asked the question if the faith comforted them and encouraged them and $73 \%$ of respondents answered affirmatively, I do not know was the response of $7 \%$ of respondents and $20 \%$ of respondents claimed religion did not encourage them (Črpić and Zrinščak, 2010: 12). Although the comparison of the general population with the tested sample of the handball players in this paper can only be conditional, it is interesting that the comparison indicates a high percentage of the total population in which a total of $27 \%$ of the respondents consider that religion does not encourage them or they do not know, whereas only $1 \%$ of the tested handball players said that their faith was never important in the answers to the meaning of life and 5\% said that religion was sometimes essential. Terry Jonas Egli (2013) in his thesis brings an interesting fact stated by Storck, Koksky, Silvestri and Storch (2001) and Storch, Roberti, Bravata and Storch (2004) who found that athletes are more religious than non-athletes (Terry Jonas Egli, 2013: 58). One of the causes of the greater religiosity of the athletes certainly lies in the fact that the sport today has become a highly profitable reality 
which contains specific lifestyle with constant pressure, uncertainty in spite of all the efforts that have been made, the struggle for survival in conditions of strong competition. The modern professional sport has become a kind of a warfare, a warfare in peace. Through sports activities there is a struggle against rivals, but also against oneself. When it comes to professional sports, then it is a struggle for the realization of their own existence. Only at the spiritual level man can cope with the challenges that go beyond his limits and possibilities. Prayer is an important indicator of personal religiosity, $71 \%$ of respondents regularly prays in the cases of need or distress, and $28 \%$ of respondents pray often. For handball players that were surveyed the reliance on God's will and living according to God's 10 Commandments is extremely important. $66 \%$ of respondents wonder what God wants when making everyday decisions, and $21 \%$ of them do it often. The research results show that the experience of God's closeness is very close to the subjects. When asked whether there are situations in which they feel the presence of God, $57 \%$ of respondents regularly feels the presence of God, $42 \%$ feel it often, and $1 \%$ sometimes. It is interesting that none of the respondents provided a negative reply, or claimed they had never felt the presence of God. These answers lead us back to Victor Frankl's thought who claims that just "asking for the meaning means to be religious" (Frankl, 2001: 81).

For the respondents, the ethical-moral principle is extremely important and it is on their foundations that they make everyday decisions. Living according to God's commandments is for them very current and should not be considered obsolete. The following question: When you are absolutely sure that no one will discover it, will you take something not yours or will you commit a fraud, was answered by $62 \%$ of respondents negatively (never), 36\% of them do it sometimes and 3\% of them often. The replies sometimes and often imply a possibility to opt for a lie or fraud if a situation calls for it. Only a strong positive intrinisic motivation and a clear positive attitude can withstand the challenges of external situations. Only exclusively identifying the good, the internal need and motivation directs and empowers a man for good. By exploring the views of professional and recreational athlete respondents on the ethics of today's athletes, Brkljačić et al. showed that $6.1 \%$ of respondents completely agree that athletes are ethical, while $37.4 \%$ of respondents agree with this statement. A high percentage of $44.4 \%$ of respondents have no opinion on the above claims, $11.1 \%$ of respondents disagree with the statement that athletes are ethical, while $1 \%$ of the respondents fully disagree with this statement (Brkljačić et al., 2011: 98).

When asked if they try to do well even to those they know will not do well in return, $48 \%$ of respondents regularly tries to help and do good, $50 \%$ do so often and $2 \%$ at times. To err, forgive or admit mistakes is all a part of the experience a man is exposed to on everyday basis, but these situations burden and cause discomfort and guilt. According to Ivančić to forgive is not only the ethical principle but also a spiritual remedy. The hatred destroys the body as well, not only the psyche. By forgiving a man frees himself from hatred, becomes free and can function as a whole human being (Ivančić, 2016b: 11). The following question: Do you pray God for forgiveness if you make mistakes, was answered regularly by $51 \%$ of respondents, often by $44 \%$ and sometimes by $5 \%$.

With regard to gender, the third hypothesis that there is no statistically significant difference in the average scores given to gender can partially be confirmed. For answers to five questions (out of 13 questions) there is an evident difference in the average according to the gender. For example, women do good to those who know that they will not do good in return $(\mathrm{m}=3.64)$ compared to men $(\mathrm{m}=3.3)$. Men are not reluctant to admit a mistake and apologize if necessary $(\mathrm{m}=3.76)$ when compared to women $(\mathrm{m}=3.64)$.

\section{Conclusion}

Using the method of self-perception handball players were asked to assess their own attitudes toward faith, prayer, meaning, relationship with God, and the impact of moral values in everyday decisions. The obtained results show that for the tested handball players faith, prayer and God's commandments are the inner force that directs and determines external actions and gives meaning to everything they do. The results show that faith is regularly or often important for $94 \%$ of respondents when reflecting on the meaning of his life. $99 \%$ of respondents pray in the case of need or distress regularly and often, $87 \%$ wonder what God wants when making everyday decisions regularly or often. Only $1 \%$ of respondents believe the 10 Commandments of God obsolete, but $99 \%$ of respondents do not agree at all or mostly disagree with that statement. When the respondents evaluated how prone they are to taking something not theirs or commit a fraud if sure that no one will discover that, $62 \%$ of respondents said they would never do so. For $3 \%$ of it is a common practice, and the remaining $36 \%$ replied sometimes implying that in a given situation they would do so. In today's world, which is centered towards the materialistic values and in which sport often becomes a means of materialistic gain, it is not easy for the young athletes to resist all the challenges and opportunities, including the negative ones such as lies, deceit, unsportsmanlike conduct and so on. These results show how important the education is at all levels for a number of negative challenges which young athletes are exposed to. At the same time the obtained selfassessment results of respondents identify their desire and focus to good and positive communication with people and with God. In order to make the positive initial direction of young athletes their life accomplishment, 
moral and ethical education is a necessity as it will train the young athletes to build the value criteria which will enable them to morally judge actions. Only the clear and positively-oriented ways make a versatile and comprehensive development and growth possible. The search for meaning, orientation towards good and ethical-moral action can be maximized through sports activity and realized only if the person is fully developed through psycho-physical and spiritual aspect. In doing so, through faith, prayer, searching for meaning, thanksgiving, forgiveness, relationship with God and his commandments intrapersonal dimension is formed and thus positive attitudes are being built that actively influence the moral-ethical action and become visible indication of the strong and deep sport spirituality. On the other hand, relativization of good and evil, the denial of general human moral criteria, excessive individualism, one-sided emphasis and overemphasis of purely material goods and personal benefits are visible indicators of the lack of transcedental and are a sign of insufficient sports spirituality. The results of some previous studies (according to Terry Jonas Egli, 2013) have shown that athletes are more religious than non-athletes. The results and the analysis of this study confirm the high level of focus towards religiosity and spirituality, but we must bear in mind that Croatia is a small Catholic country with a traditional culture in which religion plays a major role. According to Leutar and Josipović (2008), the higher degree of the modernization of society, the lower the proportion of young people who are religious. It would be interesting to further investigate and compare the religiosity and spirituality of athletes with regard to economically more developed countries and a higher degree of modernization of the society.

The scientific contribution of this work and its research is reflected in the allocation of sport as an activity that is not related only to physical fitness and activity, but sees a man as a complex and comprehensive ontological being inherent in its anthropological dimension.

\section{References}

[1]. Blažević, J. (2014) New Age i kršćanstvo. Enciklopedijski priručnik, Verbum, Split.

[2]. Brnčić, J. (2006) Riječima ponovno uspostaviti smisao, Povodom knjige A. Chouraquija, Deset zapovijedi danas, Filozofska istraživanja, 104 God. 26 (4) 891-904).

[3]. Berger, L. P. (2008) Desekularizacija sveta. Oživljavanje religije i svetska politika, Novi Sad, Mediterran publishing.

[4]. Brkljačić, Morana (2007) Etika i sport, Medicina (43) 230-233.

[5]. Berger, L. P. (2008) Desekularizacija sveta. Oživljavanje religije i svetska politika, Novi Sad, Mediterran publishing.

[6]. Brkljačić Žagrović, M., Brkljačić Beg, S., Mavrinac, M., Sorta-Bilajac Turina, I., Bunjevac, I., Čengić, T. (2011) Može li suvremeni sport bez svoje etike? - potreba za sustavnom edukacijom, JAHR, Godišnjak Katedre za društvene i humanističke znanosti u medicini, Medicinski fakultet Sveučilišta u Rijeci, 2 (3) 93-110.

[7]. Czech, D. R., Wrisberg, C., Fisher, L., Thompson, C., \& Hayes, G. (2004) The experience of Christian prayer in sport - An existential phenomenological investigation. Journal of Psychology and Christianity, 2, 1-19.

[8]. Ćimić, $\quad$ E. (1986) Podrijetlo ravnodušnosti prema religiji i/ili prema ateizmu, file:///C:/Users/Korisnik/Downloads/3 4_7_Esad_Cimic_Podrijetlo_ravnodusnosti_prema_religiji_i_ili_prema_ateizmu\%20(1).pdf (accessed on 28/1/2017)

[9]. Ć́ Ćrić, Š S. Š. (1997) Psihologija religioznosti, II. dopunjeno izdanje, Naklada Slap, Jastrebarsko.

[10]. Črpić, G., Zrinščak, S. (2010) Dinamičnost u stabilnosti: religioznost u Hrvatskoj 1999. i 2008. godine, Društvena istraživanja, god. 19, br. 1-2 (105-106) str. 3-27.

[11]. Dučkić, A., Kokorić, S. B. (2014) Duhovnost - resurs za prevladavanje kriznih životnih situacija kod pripadnika karizmatskih zajednica, Ljetopis socijalnog rada, 21 (3) 425-452.

[12]. Egli, T. J. (2013) Doctoral Dissertations „AASP - Certified Consultants' Experiences of Spirituality within Sport Psychology Consultatiion“, PhD diss., University of Tennessee.

[13]. Fukuyama, M. A.; Sevig, T. D. (1999) Integrating spirituality into multicultural counseling, Thousand Oaks, CA: Sage.

[14]. Frankl, E. V. (2001) Bog kojega nismo svjesni. Psihoterapija i religija, V. promijenjeno i popravljeno izdanje, Biblioteka Oko tri ujutro, Zagreb.

[15]. Fowler, W. J. (1981) Stages of faith: the psychology of human development and the quest for meaning, New York: HarperCollins.

[16]. Kučiš, V., Spehnjak, M. (2015) Education activities and moral growth of the perception of athletes about their own religion. Acta kinesiologica, ISSN 1840-2976, Sep. 2015, vol. 9, suppl. 1, str. 39-46.

[17]. Ivan Pavao II. Salvifici doloris, Kršćanska sadašnjost, Zagreb, 1990.

[18]. Ivančić, T. (2011) Dijagnoza duše i hagioterapija, VIII. izdanje, Teovizija, Zagreb.

[19]. Ivančić, T. (2013) Hagijoterapija u susretu s čovjekom, Teovizija, Zagreb.

[20]. Ivančić, T. (2016a) Svestrana izranjenost čovjeka. Hagioterapija izranjenosti, Teovizija, Zagreb.

[21]. Ivančić, T. (2016b) Molitva koja liječi, XX. izdanje, Teovizija, Zagreb.

[22]. Jukić, J. (1997) Lica i maske svetoga. Ogledi iz društvene religiologije, KS, Zagreb.

[23]. Jemmer, P. (2009) Intrapersonal Communication: the Hidden Language, European Journal of Clinical Hypnosos, 9 (1) $37-49$.

[24]. Leutar, Z., Leutar, I. (2010) Religioznost i duhovnost u socijalnom radu, Crkva u svijetu, 45 (1) 78-103.

[25]. Leutar, Z., Josipović, A. M. (2008) Neke dimenzije religioznosti mladih, u: Nova prisutnost, VI (3) 373-395

[26]. Lipton, H. Bruce (2007) Biologija vjerovanja. Znanstveni dokaz o nadmoći uma nad materijom, TELEdisk, Zagreb.

[27]. Migles, Silvija (2016) Socijalna dimenzija Deset riječi: bitni sadržaj vjerskoga odgoj za današnje vrijeme, u: Lađa, God. 11, br. 4 (42) 6-16.

[28]. Novi zavjet (1993) Novi zavjet s grčkog izvornika preveli Bonaventura Duda i Jerko Fučak, Kršćanska sadašnjost, Zagreb.

[29]. Perak, B. (2010) Prema kognitivnoznanstvenom shvaćanju iskustva svetoga, Filozofska istraživanja, 117-118, God. 30, sv. 1-2, 237-267.

[30]. Parry, J., Robinson, S., Watson, J. N., Nesti, M. (2007) Sport and Spirituality An Introduction, London: Routledge.

[31]. Tomašević, L. (2015) Etike „Trećeg lica“ i moralne vrednote, Služba Božja, 55 (2) 155 - 178.

[32]. Shiah, Y. J., Chang, F., Chiang, S. K., Lin, I. M., Tam, W. C. C. (2015) Religion and Health: Anxiety, Religiosity, Meaning of Life and Mental Health, J Relig Health, 54 (1) 35-45.

[33]. Šafarić, A. (2012) Filozofija sporta, Bjelovar, Amanita. 
[34]. Watson, N. J.; Czech, D. R. (2005) The Use of Prayerin Sport: Implications for Sport Psychology Consulting, Athletic Insight, The Online Journal of Sport Psychology, Volume 7 (4) 26-35. http://www.athleticinsight.com/Vol7Iss4/PrayerPDF.pdf (accessed on $11 / 1 / 2017)$

[35]. Watson, N. J.; Nesti, M. (2005) The role of spirituality in sport psychology consulting: An analysis and integrative review of literature, Journal of Applied Sport Psychology, 17, 228-239. 